\title{
“AJA RUMANGSA BISA NANGING BISAA RUMANGSA" PESAN MORAL DALAM KEARIFAN LOKAL JAWA MELALUI CERPEN “JENENGKU: $A S U$ " KARYA KRISHNA MIHARJA
}

\author{
“AJA RUMANGSA BISA NANGING BISAA RUMANGSA” MORAL \\ MESSAGE IN JAVANESE LOCAL WISDOM OF "JENENGKU: ASU”, \\ A SHORT STORY BY KRISHNA MIHARJA
}

\author{
Yohanes Adhi Satiyoko \\ Balai Bahasa D. I. Yogyakarta \\ Jalan I Dewa Nyoman Oka 36, Yogyakarta \\ Pos-el: dhimassetiyoko@gmail.com
}

\begin{abstract}
Abstrak
Penelitian ini mengungkapkan sisi kemanusiaan dalam ranah politik yang tergambar melalui cerita pendek berbahasa Jawa (cerkak) karangan Krishna Miharja berjudul "Jenengku: Asu". Masalah dalam penelitian ini adalah bagaimana dialektika tokoh utama dengan dunia sosialnya. Tujuan penelitian adalah menjelaskan dialektika tokoh utama dengan lingkungan sosialnya, khususnya dalam usahanya memenuhi ambisi politiknya. Pembahasan dalam analisis ini menggunakan kerangka pikir sosiologi pengetahuan Peter Berger melalui dialektika proses eksternalisasi, objektivikasi, dan internalisasi. Hasil penelitian menunjukkan bahwa kegagalan tokoh utama dalam memenuhi ambisinya disebabkan karena ambisi politiknya tidak didukung oleh kemampuan dan pengetahuan yang cukup. Sikap tersebut bertentangan dengan filosofi orang Jawa "aja rumangsa bisa, nanging bisaa rumangsa", sebuah kearifan lokal untuk introspeksi diri.
\end{abstract}

Kata kunci: mawas diri, eksternalisasi, objektivasi, internalisasi, ambisi

\section{Abstract}

This research aims to reveal humanism in political field as portrayed through Javanese short story by Krishna Miharja entitled "Jenengku: Asu". Problem formulation is how the dialectic of main character to his social life. The purpose of the research is explaining the main character to his social life, particularly to his own political ambition. The discussion in the analysis uses sociology of knowledge framework of Peter Berger through dialectic process of externalization, objectivation, and internalization. The result shows that the failure of main character in fulfilling his ambition is stimulated from his political ambition without sufficient ability and knowledge. That attitude is against the Javanese philosophy "aja rumangsa bisa, nanging bisaa rumangsa", a local wisdom to self introspection.

Keywords: self introspection, externalization, objectification, internalization, ambition

\section{Pendahuluan}

"Aja rumangsa bisa, nanging bisaa rumangsa" atau "Jangan merasa bisa, tetapi bisalah merasa" adalah sebuah ungkapan kearifan lokal Jawa yang mempunyai makna universal, yaitu ajakan introspeksi diri. Kearifan lokal adalah kebiasaan baik yang dilakukan oleh masyarakat dalam kehidupannya. Kebiasaan ini tidak hanya berupa aktivitas atau perbuatan, tetapi juga dalam bentuk ekspresi sastra, tradisi relijius, dan lain sebagainya. Kearifan lokal dipandang juga sebagai sebuah nilai luhur (lofty value) dalam ajakan kebaikan (Firza, 2016: 362). Ajakan kearifan lokal Jawa ini berusaha menyapa setiap individu untuk 
menyadari segala kekurangan dan kelebihan diri, menimbang setiap langkah, menjadi rendah hati, mau melihat orang lain yang mempunyai kemampuan berbeda dengan diri sendiri. Inti kearifan ini adalah pemahaman terhadap kemampuan diri ketika akan melakukan sebuah tindakan, apakah diri sendiri mampu, kuat, tepat, atau tidak. Jangan sampai diri sendiri merasa mampu padahal sebenarnya tidak mampu, tidak mempunyai modal, tidak mempunyai pengetahuan, tidak mempunyai visi-misi, serta berbagai hal yang dibutuhkan untuk melaksanakan dan mengemban tugas yang dihadapinya. Jika seseorang tetap memaksakan keinginan dan tidak pernah mampu menakar kemampuan diri (bisa rumangsa), maka kekonyolan, bahkan nasib tragis akan menjadi akhir langkah atau karier mereka.

Kearifan Jawa "aja rumangsa bisa, nanging bisaa rumangsa", seperti kearifankearifan Jawa lain muncul sebagai respon kehidupan sosial yang perlu dikritisi. Zaman milenial seperti sekarang ini banyak ditemui para oportunis di berbagai bidang kehidupan, yang tentunya menjanjikan profit dan kuasa. Dunia politik adalah salah satunya. Dunia politk adalah magnet ketenaran, simbolisasi sebuah kekuasaan, parameter sebuah keberhasilan. Fenomena panggung perpolitikan tersebut merupakan bagian dari sebuah dinamika kehidupan masyarakat dalam struktur sosial tempat mereka tinggal dan berinteraksi. Segala sesuatu yang kita lakukan terletak dan dipengaruhi oleh struktur sosial tempat kita tinggal (Wollf, 1981: 9).

Sejak zaman Yunani kuno, intrik untuk menjadi politikus sudah tergambar, baik dalam sejarah, seni pertunjukan, maupun dalam sastra. Sejak zaman Calligula sampai dengan zaman milenial, magnet dunia politik seakan menjadi iming-iming bagi segelintir orang. Jika disertai kemampuan yang mumpuni dan tujuan yang luhur untuk memperjuangkan kehidupan berbangsa dan bernegara, maka dukungan rakyat layak diperoleh. Akan tetapi, fenomena dewasa ini di Indonesia, setiap orang dari segala latar belakang berusaha masuk ke panggung politik. Tak jarang drama perpolitikan di Indonesia hanya menjadi tontonan yang menggelikan dan konyol. Kekonyolan tersebut lalu direkam oleh para pengarang menjadi sebuah suguhan karya sastra yang berfungsi mengeritik tetapi dalam kemasan estetis.

Cerkak-cerkak (cerita pendek berbahasa Jawa) karya Krishna Miharja yang terangkum dalam Pratisara (pemenang penghargaan Rancage tahun 2014 sebagai karya sastra Jawa terbaik) berkisah tentang drama-drama kemanusiaan yang erat hubungannya dengan politik dan kekuasaan. Gambaran masyarakat, pemimpin masyarakat, tabiat penguasa, ambisi seseorang menjadi wakil rakyat, dan lain sebagainya dipaparkan oleh Krishna dalam satu paparan yang bersifat anekdot dan satire. Selain sebagai sebuah ekspresi kesastraan yang estetis untuk dibaca, cerkakcerkak dalam Pratisara juga menyumbangkan kritik sosial yang tidak berjarak dengan pembaca.

Cerkak berjudul "Jenengku: asu" bergaya ekspresi satiris dan anekdotal. Cerkak tersebut merespon fenomena dunia perpolitikan yang terjadi di Indonesia. Rumusan masalah dalam penelitian ini adalah bagaimana menemukan dialektika individu tokoh utama dengan dunia sosial budayanya. Dialektika tersebut tergambar dalam tiga proses interaksi individu dengan dunia sosial budayanya, yaitu melalui eksternalisasi, obyektivikasi, dan internalisasi. Tujuan penelitian adalah mengetahui dan menjelaskan dialektika tersebut melalui pembacaan makna-makna dan perlambangan yang disimbolkan dalam tokoh, alur, dan latar serta menemukan simpulan dari perlambang-perlambang yang diperoleh.

\section{2. $\quad$ Metode}

Pembahasan cerkak "Jenengku: Asu" akan memanfaatkan pandangan sosiologi pengetahuan Peter Berger (1990: xiv-xx), yaitu melihat fenomena sosial budaya yang berangkat dari kenyataan kehidupan sehari- 
hari (lebenswelt) sebagai realitas utama gejala bermasyarakat. Fenomena sosial yang dimaksudkan adalah sikap-sikap subyektif yang wajar dan alamiah dengan memperhatikan faktor dialektika antara diri (the self) dengan dunia sosio-kultural, yakni eksternalisasi diri (penyesuain diri dengan dunia sosio-kultural sebagai produk manusia), obyektifikasi (interaksi sosial dalam dunia intersubyektif yang dilembagakan atau mengalami proses institusionalisasi), dan internalisasi diri (individu mengindentifikasikan diri dengan lembaga sosial atau organisasi tempat individu tersebut menjadi anggotanya). Dialektika tersebut muncul dalam bahasabahasa verbal dan non verbal yang menyimbolkan atau menandai sesuatu dalam kehidupan manusia (Berger 1990: 49-52). Hasil pembacaan dialektis tersebut secara sosiologis mewujud menjadi sebuah pengetahuan bagi masyarakat.

Latar belakang sosial budaya tersebut di atas akan mendasari pembahasan berikutnya, yaitu melihat perwatakan tokoh utama, latar penceritaan, dan alur cerita. Latar sosial budaya dibahas sesuai dengan konteks masalah, yaitu ambisi seseorang menjadi anggota dewan tanpa dibekali dengan modal pengetahuan dan kecakapan yang memadai.

Pembahasan berikutnya, yaitu menunjukkan apakah tokoh Denmas Lakon melaksanakan proses dialektika melalui tiga momen simultan, eksternalisasi, objektivasi, dan internalisasi. Hasil pembacaan terhadap perwatakan, latar, dan alur cerita dengan tokoh utama Denmas Lakon tersebut dalam dialektikanya dengan lingkungan sosial budayanya, dirumuskan menjadi temuan yang ditafsirkan dan dipaparkan sebagai simpulan penelitian untuk menunjukkan watak tokoh utama.

\section{Pembahasan}

\subsection{Cerkak "Jenengku: Asu" dalam Fenomena Sosial Budaya}

Cerita pendek berbahasa Jawa (cerkak) "Jenengku: Asu" adalah karya Krishna Miharja bergaya anekdotal dan satiris, yaitu cerita yang menggelikan dan mengandung sindiran kepada satu "riwayat hidup" pribadi tertentu (Danandjaya, 1991: 118). Cerkak berjudul "Jenengku: asu" memaparkan seorang pengusaha yang kaya yang berambisi menjadi anggota dewan yang bakal dihormati. Keinginan pengusaha tersebut sudah ditentang oleh istrinya, karena pengusaha itu tidak tahu apa-apa tentang tugas dan fungsinya sebagai anggota dewan yang terhormat. Namun, semua peringatan istrinya tidak digubris sama sekali. Dia tetap bersikeras menjadi anggota dewan. Setelah dilantik, anggota dewan tersebut dicemooh oleh masyarakat karena kebodohannya. Bahkan dia digambarkan tidak mampu berbicara dan menyebutkan nama dirinya sendiri dengan benar. Dia gagap. Dia akhirnya hanya mampu menyebut dirinya sendiri sebagai asu atau anjing. Akhirnya, si pengusaha tersebut bisa berbicara dengan lancar setelah disembuhkan, namun tubuh pengusaha tersebut berubah menjadi anjing. Den Lakon berubah menjadi anjing dengan segala tingkah lakunya. Sorotan akan sosok diri, keluarga, pekerjaan, catatan kehidupannya, sepak terjangnya, dan akhir perjalanan karirnya akhirnya menjadi konsumsi publik.

Suksesi kepemimpinan selalu menjadi topik menarik untuk disimak dalam sejarah umat manusia. Pemilihan kepala daerah, dari presiden, gubernur, sampai kepala desa sebagai pemimpin daerah sering menyisakan masalah, seperti ketidakpuasan massa pendukung pasangan, politik uang yang berhasil dibongkar, hingga sampai pada praktik perdukunan untuk memuluskan suksesi. Fenomena tersebut menjadi bagian kehidupan kita sehari-hari. Fenomena ini diangkat oleh Krishna Miharja dalam ekspresi cerkak

Tokoh Denmas Lakon dalam "Jenengku: Asu" digambarkan sebagai seorang pengusaha yang kaya raya. Walaupun sudah kaya, Denmas Lakon tetap tertarik untuk menjadi seseorang yang lebih kaya, berkuasa, disegani, dan dapat memperoleh beraneka proyek. Iming-iming jabatan sebagai anggota dewan menjadi daya tarik baginya. Dia ingin terkenal, kaya, dan 
menentukan gajinya sendiri. Sudah menjadi rahasia umum bahwa anggota dewan bisa menentukan dan memutuskan berbagai hal yang kaitannya dengan pembiayaan, tidak terkecuali pengadaan proyek-proyek bertaraf nasional. Hal ini sering dijumpai dalam berita-berita di media massa dan media sosial, bahkan ketika anggota dewan tersebut akhirnya terjebak dan tertangkap tangan oleh pihak berwajib atau KPK untuk mempertanggungjawabkan perbuatannya. Seorang anggota legislatif yang berteriak melawan korupsi ternyata akhrinya tertangkap karena melakukan korupsi. Hal semacam ini muncul karena pendidikan politik tidak diterapkan bagi para calon anggota legislatif tersebut. Fokus kampanye adalah masalah ketenaran semata (Mustika dan Arifianto, 2018: 140-141). Rupanya perbandingan antara ketenaran, kekayaan, dan kekuasaan menjadi politikus dan anggota dewan dan tindakan ceroboh mereka memperkaya diri sendiri tidak diperhatikan oleh sebagian masyarakat. Hal inilah yang akhirnya menjadi iming-iming bagi masyarakat untuk berambisi menjadi politikus dan anggota dewan supaya mempunyai kekuasaan dan kekayaan, walaupun sebenarnya kemampuan dan pengetahuan mereka sangat tidak memadai untuk itu. Iming-iming ketenaran, kekuasaan yang seakan menjadi tren dan gaya hidup orang-orang tertentu tergambar dalam kutipan berikut.

"Aiyak wektu iki politikus iku segalanya, Bu. Apa meneh bisa dadi anggota dewan. Ngendi ana wong nyambut gawe bisa ngatur lan nemtokake bayare dhewe, liyane dadi anggota dewan. Kamangka, saliyane anggota dewan...aku uga isih dadi pengusaha. Wis...kabeh proyek tak garap dhewe." (Pratisara, 2013: 124)

Terjemahan:

"Aiyak...sekarang ini politikus adalah segalanya, $\mathrm{Bu}$. Apa lagi bisa menjadi anggota dewan. Mana ada orang bekerja bisa mengatur dan menentukan gajinya sendiri, selain jadi anggota dewan. Padahal, selain anggota dewan...aku juga masih jadi pengusaha. Sudahlah...semua proyek kutangani sendiri." (Pratisara, 2013: 124)

Ambisi Denmas Lakon tersebut benarbenar tidak didukung oleh kemampuan dan pengetahuan yang cukup untuk menjadi seorang politikus dan anggota dewan. Dia tetap kukuh pada niatnya ketika istrinya menasihatinya untuk membatalkannya. Dengan menghabiskan uang berjuta-juta akhirnya Denmas Lakon berhasil terpilih menjadi anggota dewan. Isi hati Denmas Lakon berbeda dengan apa yang selalu dia ucapkan kepada masyarakat di masa kampanye. Akhirnya dia menderita sakit bicara, yaitu salah-salah ketika mengatakan sesuatu. Hal ini menjadi heboh ketika Denmas Lakon dilantik. Isi hatinya terungkap melalui kata-katanya secara tidak sadar tetapi tetap terucap.

Nalikane diwisuda dadi anggota dewan Dnmas Lakon babar pisan ora bisa nyebut jenenge dhewe.

"jenengku

Sulak...Sulaa...Sulll...Suuu...jenengku

Suuuu...," Denmas Lakon ora bisa ngeja jenenge. Gagap.

Sing wadon, banget anggone bingung meruhi sing lanang babar pisan ora bisa ngeja jenenge dhewe iku.

"Jenengku. Su jenengku assuuuu. Jenengku Asu," cetha lan teteh banget pocapane Denmas Lakon.

Kahanan dadi geger, gemrenggeng kaya tawon gula digosok talane. Ana kang nyenyenges, ana sing njegeges anggone ngguyu. Ana kang nggresah alon karo ngelus dhadha. Ana kang cekikikan sajak ngece. (Pratisara, 2013: 126)

Terjemahan:

Ketika diwisuda menjadi anggota dewan. Denmas Lakon sama sekali tidak bisa menyebut namanya sendiri.

"Namaku

Sulak...Sulaa...Sulll...Suuu...namaku

Suuuu...," Denmas Lakon tidak bisa mengeja namanya. Gagap.

Istrinya, sangat bingung melihat suaminya sama sekali tidak bisa mengeja namanya sendiri. 
"Namaku. Su namaku assuuuu. Namaku Asu," jelas dan tegas sekali ucapan Denmas Lakon.

Keadaan menjadi gempar, mendengung seperti lebah gula yang digosok sarangnya. Ada yang menyindir, ada yang mengejek sambil tertawa. Ada yang menghela napas pelan sambil mengelus dada. Ada yang cekikikan mengejek. (Pratisara, 2013: 126)

Kutipan di atas secara gamblang menunjukkan sebuah dekonstruksi jabatan politikus anggota dewan yang dianggap terhormat di mata masyarakat, tetapi melalui Denmas Lakon jabatan tersebut menjadi sebuah hal yang remeh-temeh dan sangat tidak berharga. Penggambaran dekonstruktif tersebut disimbolkan dengan penghadiran latar suasana wisuda anggota dewan. Pada wisuda yang seharusnya berlangsung formal, khidmat, dan terhormat menjadi kacau balau karena tokoh Denmas Lakon yang dilantik ternyata tidak mampu menyebutkan nama dirinya sendiri. Ucapan yang keluar dari mulut Denmas Lakon adalah "jenengku asu" atau "namaku anjing".

Perlambangan anjing merupakan perlambangan yang sangat rendah jika dikomparasi dengan derajat manusia. Anjing adalah hewan yang dianggap najis (dalam agama tertentu) dan berderajat di bawah hewan-hewan lain yang sering berada di sekitar kehidupan manusia, seperti kambing, sapi, ayam, kucing, burung, dan lain sebagainya. dengan demikian penghadiran simbol anjing dalam derajat sejajar dengan manusia merupakan sebuah satire yang sangat dalam dan merendahkan derajat manusia jauh di bawah batas derajat terbawah manusia. Secara fungsional dapat dipahami bahwa Denmas Lakon adalah simbol ambisi manusia yang rendah, tidak berotak waras, namun berambisi menjadi orang terhormat dan kaya. Hal ini pun mengimplikasikan sebuah perumpamaan bahwa ambisi manusia untuk menjadi terhormat, tetapi hanya bermodal seperti binatang, seperti seekor anjing.

\subsection{Ambisi dan Kemampuan Diri}

Dialektika hubungan antara individu, yaitu sosok tokoh Denmas Lakon dalam "Jenengku: asu" dipilah melalui momen simultan, yaitu eksternalisasi, objektivasi, dan internalisasi. Berikut penjelasannya.

\subsubsection{Eksternalisasi}

Tataran eksternalisasi, yaitu penyesuaian diri individu dengan dunia sosial budaya buatan manusia. Dunia sosial budaya yang dimaksud dalam "Jenengku: Asu" adalah keharusan Denmas Lakon untuk bersosialisasi kepada masyarakat, karena dia mencalonkan diri menjadi wakil rakyat. Mekanisme pencalonan secara administratif juga perlu dijalani, seperti latar belakang pendidikan, keahlian yang dipunyai, kesiapan mental, bahkan fit and proper test (uji kelayakan). Dalam hal ini Denmas Lakon mengabaikan mekanisme yang harus dijalani untuk memperoleh jabatan sebagai anggota dewan, sehingga tidak terjadi penyesuaian diri dengan tatanan yang berlaku. Politik uang dengan menghamburhamburkan banyak biaya untuk memperoleh suara dilakukannya, apalagi dirinya adalah seorang pengusaha yang sudah mempunyai banyak uang.

Denmas Lakon tetep ngeyel, lan sing wadon sidane ora bisa menggak kekarepane sing lanang. Dhuwit mayuta-yuta mawut dienggo melu kampanye. (Pratisara, 2012: 124)

Terjemahan:

Denmas Lakon tetap ngotot, dan istrinya akhirnya tidak dapat menahan keinginan suaminya. Uang berjuta-juta dihamburkan untuk ikut kampanye (Pratisara, 2012: 124)

Ambisi tokoh Denmas Lakon untuk menjadi politikus, anggota dewan sangat kuat dengan persepsi bahwa dia akan memperoleh semua yang diinginkannya. Menjadi anggota dewan mensyaratkan sebuah pengetahuan yang sangat luas tentang berbagai hal dalam kehidupan manusia. Selain itu diperlukan juga mental kenegarawanan dan kemampuan retorika 
(tidak gagap komunikasi) untuk berkomunikasi secara konstruktif kepada rakyat. Dan yang paling penting adalah kejujuran dan ketulusan, untuk melayani. Hal ini menjadi dasar bagi sebuah pesta demokrasi yang diikuti oleh calon-calon anggota legistalif, bahwa pemilu merupakan sarana demokrasi yang mendasarkan pada ekspresi kedaulatan rakyat yang nantinya menghasilkan wakil-wakil rakyat yang aspiratif, berkualitas, serta mampu bertanggung jawab untuk menyejahterakan rakyat (Wardhani,2018: 58), bukan pemimpin yang ambisius akan kuasa dan kekayaan.

\subsubsection{Objektivasi}

Objektivasi, yaitu sebuah interaksi sosial dalam dunia intersubjektif. Dalam dunia pemerintahan terdapat interaksi antar perangkat pemerintahan untuk membangun komunikasi konstruktif dalam menjalankan roda pemerintahan secara baik. Seorang individu yang akan mencalonkan diri menjadi wakil rakyat, dia harus menjadi bagian dari institusi-institusi sosial yang berorientasi kemasyarakatan. Selama masa kampanye, seorang calon anggota dewan seharusnya menyatakan berbagai ide dan gagasan untuk menyejahterakan rakyat, bukan sebaliknya berpikiran memperoleh keuntungan dari rakyat untuk kepentingan kekuasaan dan kekayaan diri sendiri.

Selain itu, Denmas Lakon tidak melalukan aktivitas objektivasi, yaitu dengan memperhatikan dan memenuhi syarat dan kebutuhan seorang anggota dewan (fit and proper test). Denmas Lakon hanya memperhatikan keuntungan finansial melalui kekuasaan menjadi seorang anggota dewa sehingga mengesampingkan mekanisme administratif yang berlaku.

Sebagai seorang calon anggota dewan, Denmas Lakon harus mempunyai mekanisme yang konstruktif membangun jalur birokrasi yang bebas korupsi dan nepotisme. Akan tetapi, ambisi Denmas Lakon adalah sebaliknya, yaitu ingin menciptakan jalur birokrasi yang menguntungkan diri sendiri.
"Eih...kabeh proyek iku nganggo lelang, to?"

"Ohoi, lelang? Kaya adat sabene, lelang iku mung dienggo singlon thok," kandhane Denmas Lakon.

"Karo meneh, suk yen aku wis dadi anggota dewan, aturan iki kudu diganti. Kabeh proyek ora kudu dilelang, nganggo PeeL. Penunjukan Langsung. Pira suwene gawe aturan anyar." (Pratisara, 2012: 124).

Terjemahan:

"Eih...semua proyek itu palai lelang, kan?"

"Ohoi, lelang? Seperti biasanya saja, lelang hanya sebagai kamuflase saja," kata Denmas Lakon.

"Lagipula, besok kalau aku sudah jadi anggota dewan, aturan ini harus diganti. Kabeh proyek tidak harus dilelang, melalui PeeL. Penunjukan Langsung. Berapa lama sih buat aturan baru." (Pratisara, 2012: 124).

Pernyataan Denmas Lakon menunjukkan bahwa aktivitas objektivasi tidak terjadi antara calon anggota dewan dengan rakyat. Ambisi pribadi Denmas Lakon adalah memperkaya diri sendiri. Syarat menjadi anggota dewan sama sekali tidak dipenuhi oleh Denmas Lakon.

\subsubsection{Internalisasi}

Proses internalisasi diri tidak ditunjukkan oleh Denmas Lakon sesuai dengan jabatan yang disandangnya. Internalisasi diri Denmas Lakon sebagai anggota dewan sama sekali tidak muncul, karena semua syarat dan kebutuhan sebagai seorang anggota dewan tidak pernah diketahui dan dipenuhinya. Kesadaran dan sifat koreksi diri (Jawa: bisaa rumangsa) dominan mengemuka dalam dirinya. Denmas Lakon mendasarkan dirinya pada perasaan bahwa politik lebih berhak bagi mereka yang punya pengalaman dan status sosial yang cukup (Wardhani, 2018: 61). Pemahaman yang tidak sepenuhnya benar inilah yang menyebabkan Denmas Lakon merasa dirinya mampu menjadi wakil rakyat dengan status sosial yang tinggi dan kekayaan yang dipunyainya. Dia lupa kalau 
dirinya tidak mempunyai pengalaman yang cukup.

Ambisi Denmas Lakon menjadi anggota dewan sebenarnya sudah dilarang oleh istrinya. Istri Denmas Lakon sangat mengerti kemampuan Denmas Lakon sebagai seorang pengusaha. Berkali-kali Denmas Lakon dievaluasi oleh istrinya supaya menginternalisasi diri sesuai dengan bidang keahliannya saja, tidak coba-coba berperan melebihi kemampuan dirinya.

"Pak, dadia macan kaya macan tenan, geneya yen dadi wedhus iya kaya wedhus temenan. Kowe iki kiraku wis didhapuk dadi pengusaha, keneng apa ndadak dadi politikus, karo meneh apa bathine dadi politikus?" kandhane sing wadon. (Pratisara, 2012: 124)

Terjemahan:

"Pak, jika jadi harimau jadilah harimau beneran, sedangkan jika jadi kambing jadilah kambing beneran. Kamu kan sudah ditakdirkan menjadi pengusaha, mengapa malah berusaha menjadi politikus, lalu apa keuntungan jadi politikus?" kata istrinya. (Pratisara, 2012: 124)

Kata-kata istri Denmas Lakon tersebut menunjukkan bahwa Denmas Lakon tidak mau dan mampu menginternalisasi diri sesuai profesinya. Dia mengingkari dan berusaha berprofesi lain, sebagai politikus, tanpa berbekal modal pengetahuan dan keterampilan yang cukup. Jangankan memperjuangkan kepentingan rakyat, beretorika saja Denmas Lakon tidak sanggup. Akhirnya, satu hal yang dia bisa lakukan adalah berujar bahwa namanya adalah asu atau anjing. Simbolisasi ini secara fungsional menunjukkan bahwa dia menelanjangi dirinya sendiri, menunjukkan jati dirinya sendiri. Seperti ungkapan srigala berbulu domba, maka dapat juga disejajarkan bahwa apa yang dilakukan Denmas Lakon adalah anjing berbadan manusia. Pernyataan istri Denmas Lakon di atas, secara implikatif mengajak Denmas Lakon untuk tahu diri, mempunyai dan mengingat budaya malu yang berkembang dalam tatanan sosial yang normatif. Dengan budaya malu yang tinggi, maka karakter dan kualitas manusia akan terlihat (Iswari, Handayani, dan Nuriyanti, 2019: 86). Implikasinya adalah, individu akan sadar dan tahu posisi dirinya serta mampu menginternalisasi diri sebagaimana mestinya.

\subsection{Aja Rumangsa Bisa Nanging Bisaa Rumangsa}

Dialektika yang dipaparkan dalam tiga momen simultan tersebut menunjukkan bahwa antara individu dengan lingkungan sosial budayanya tidak terjadi interaksi yang semestinya. Sebagai individu Denmas Lakon merasa diri aman melakukan tindakan yang dirasanya benar, namun tidak aman secara obyektif. Hal tersebut terlihat dari akhir cerita tragis, yaitu Denmas Lakon menelanjangi dirinya sendiri dengan menunjukkan bahwa dirinya sebenarnya hanyalah manusia yang berwatak anjing (Jawa: $a s u$ ). Tindakan tokoh Denmas Lakon merupakan bukti ketidakmampuan diri untuk melihat potensi dalam diri sendiri. Ambisi yang didasari oleh anggapan bahwa politikus merupakan sebuah "profesi" untuk dapat mengatur keuangan sudah mengakar urat di benak Denmas Lakon. Denmas Lakon berusaha menciptakan kekuasaan melalui cara-cara yang instan, yaitu menjadi anggota dewan. Iming-iming, budaya berlomba menjadi anggota dewan, dan angan-angan bahwa menjadi anggota dewan akan menyejahterakan kehidupan melalui kekuasaan dan kekayaan rupanya sudah menjadi budaya yang tidak dapat dihindari mengakar urat di setiap kepala orang yang ambisius dan egois.

Kemampuan diri dapat muncul sebagai sebuah kekuasaan yang mengatur diri sendiri. Kekuasaan adalah kemampuan atau kesanggupan berbuat sesuatu. Kekuasaan dapat berasal dari diri sendiri untuk mengatur diri sendiri dan dapat pula dari diri untuk mengatur orang lain. Legitimasi moral kekuasaan tergantung dari cara bagaimana kekuasaan itu diperoleh dan bagaimana pemakaiannya (Magnis-Suseno, 1991: 110). Implementasi dan idealisme kekuasaan 
sangat dipengaruhi oleh pengetahuan individu yang diperolehnya dari interaksi intersubjektivitas dalam dunia sosial. Panggung politik adalah ajang kontestasi kekuasaan individu dengan tujuan-tujuan yang beragam.

Fenomena panggung perpolitikan tersebut merupakan bagian dari sebuah dinamika kehidupan masyarakat dalam struktur sosial tempat mereka tinggal dan berinteraksi. Segala sesuatu yang kita lakukan terletak dan dipengaruhi oleh struktur sosial tempat kita tinggal (Wollf, 1981: 9). Maka, sebagai makhluk sosial manusia harus dapat beraktivitas sesuai dengan lingkungan sosial budaya tempatnya tinggal. Manusia secara ideal harus membangun interaksi konstruktif dengan lingkungan sosialnya sebagai wujud kreativitas dan tindakan inovatif yang disandangnya. Sebagai insan kreatif dan inovatif, manusia mempunyai modal kuasa yang dapat diterapkannya untuk berinteraksi dan memperoleh cita-cita.

Kegagalan ketiga tokoh Denmas Lakon dalam "Jenengku: asu" menunjukkan fenomena kemanusiaan yang kontraproduktif. Keadaan kontraproduktif tersebut terjadi karena tindakan para tokoh untuk memenuhi keinginan mereka tidak diimbangi dengan modal yang cukup. Modal tersebut adalah pengetahuan, sikap mental, keterampilan dan keahlian tertentu, ataupun material.

Denmas Lakon yang seharusnya memperoleh kehormatan menjadi politikus dan anggota dewan, akhirnya menjadi terhina karena ternyata dirinya mewujud menjadi seekor anjing (anjing berbadan manusia). Seekor binatang tidak akan dapat menyamai prilaku manusia, sepintar apapun binatang itu. Maka, ketika simbolisasi Denmas Lakon, seorang manusia yang berambisi memperoleh kekayaan dan kekuasaan digambarkan mempunyai watak seperti anjing, dengan membahasakan dirinya sebagai asu atau anjing, dan akhirnya tubuhnya maujud sebagai anjing. Ini menunjukkan sebuah ketidakmampuan diri, yaitu binatang yang ingin menyamai manusia. Lagipula, gambaran anjing adalah gambaran binatang, sebuah simbol kehinaan. "Binatang" yang berkeinginan menjadi manusia adalah sebuah ketidakmungkinan, pemaksaan diri, namun tetap dilakukan oleh Denmas Lakon. Di dalam budaya masyarakat Jawa, sikap seperti ini dianggap sebagai sikap tidak tahu diri, tidak tahu malu, tidak bisa mengoreksi diri. Drama kemanusiaan tersebut dianggap sebagai sebuah tindakan yang "aja rumangsa bisa, nanging bisaa rumangsa", atau dalam bahasa Jawa disebut "jangan merasa bisa tetapi bisalah merasa". Jelas, tindakan Denmas Lakon tersebut tidak mengindahkan perasaan malu terhadap diri sendiri, terdahap sesama manusia, dan bahkan kepada Tuhan (Susanti, 2014; dalam Iswari, Handayani, dan Nuriyanti, 2019: 81). Bahkan dapat dikatakan Denmas Lakon mempunyai sifat mental yang suka menerabas atau mengambil jalan pintas untuk mencapai tujuannya (Koentjaraningrat, 1991: 45), tanpa mawas diri.

Falsafah Jawa "aja rumangsa bisa, nanging bisaa rumangsa" ini adalah falsafah sederhana, tetapi mempunyai makna universal yang mengingatkan manusia untuk mampu menyeimbangkan diri antara keinginan (demand) dan kemampuan (supply). Keseimbangan inilah yang akhirnya membedakan antara manusia yang berpikir sebelum bertindak dan bertindak tanpa berpikir.

\section{Simpulan}

Sikap wawas diri adalah sebuah sikap evaluatif bagi setiap orang. Sikap seperti ini menjauhkan diri dari tindakan-tindakan "bodoh" yang berpotensi merugikan orang lain. Pepatah Jawa "aja rumangsa bisa, nanging bisaa rumangsa" merupakan seruan preventif dalam konteks kearifan lokal Jawa untuk menakar ambisi atau keinginan diri supaya empan papan (tahu diri di tempat yang didatangi, menyesuaikan diri dengan suasana yang ada), waktu, kebutuhan, dan suasana. Ajakan wawas diri ini utamanya ditujukan bagi mereka yang berambisi menjadi pemimpin, supaya mereka 
introspeksi diri terlebih dahulu, jujur terhadap kemampuan, dan keinginan mereka sebelum mencoba meraih posisi atau kedudukan tertentu. Cerkak "Jenengku: Asu" menjadi satu ekspresi kesusastraan, cermin masyarakat yang menggambarkan kontestasi kebodohan dan kebobrokan moral (calon) "pemimpin" masyarakat dalam perlambangan binatang asu atau anjing sebagai jati diri individu dalam topeng manusia.

\section{Daftar Pustaka}

Berger, Peter. (1990). Tafsir Sosial atas Kenyataan. Risalah tentang Sosiologi Pengetahuan. Jakarta: LP3ES.

Danandjaya, James. (1991). Folklore Indonesia. Ilmu Gossip, Dongeng, dan Lain-Lain. Jakarta: Grafiti.

Darmasoetjipta, F.S. (1985). Kamus Peribahasa Jawa. Yogyakarta: Kanisius.

Firza. (2016). Local Wisdom Sebagai Dasar Dalam Pembentukan Karakter. Prosiding Seminar Nasional Reforming Pedagogi. Halaman 361365.

Iswari, Fitria, Dian Handayani, Widya Nuriyanti. (2019). "Sosialisasi Budaya Malu di Kalangan Pelajar melalui Infografis sebagai Bentuk Pendidikan Karakter". Jurnal Desain, Volume 06 Issue, 02 Januari-April 2019. Halaman $77-88$.

Koentjaraningrat. (1992). Budaya Mentalitas, dan Pembangunan. Jakarta: Gramedia.

Magnis-Suseno, Franz. (1991). Etika Jawa. Sebuah Analisa Filosofi tentang Kebijaksanaan Hidup Jawa. Jakarta: Gramedia.

Miharja, Krishna. Pratisara. (2012). Pratisara. Yogyakarta: Leutikaprio.

Mustika, Rieka. Arifianto. (2018). "Komodifikasi "Popularitas Selebritis" untuk Mendulang Suara Pemilu Legislatif 2019". Jurnal Studi Komunikasi dan Media. Volume 22 No. 2 (Desember 2018). Hal. 139150.
Utomo, Sutrisno Sastro. (2007). Kamus Lengkap Peribahasa Jawa-Indonesia. Yogyakarta: UII-Press

Wardhani, Primandha Sukma Nur. (2018). "Partisipasi Politik Pemilih Pemula dalam Pemilihan Umum". Jurnal Pendidikan Ilmu-Ilmu Sosial (10) (1) (2018): 57-62.

Wolff, Janet. (1981). The Social Production of Art. United States of America: St. Martin's Press, Inc. 